\title{
The Effects of Exchange Rates on Macroeconomic Variables: A Study on Selected Emerging Economies
}

\author{
Asst. Prof. Dr. Birgül Cambazoğlu (Haliç University, Turkey) \\ Assoc. Prof. Dr. Hacer Simay Karaalp (Pamukkale University, Turkey) \\ Assoc. Prof. Dr. Konstantinos Vergos (University of Portsmouth, United Kingdom)
}

\begin{abstract}
The exchange rate channel of the monetary transmission mechanism has gained importance through widespread use of the floating exchange rate regime with increased globalization. In this context, this study aims to explore the effectiveness of the exchange rate channel on net exports and thereby total output and price level using vector auto-regression (VAR) models. The sample countries are Turkey and Argentina, which have employed a floating exchange rate regime since 22 February 2001 and 11 February 2002, respectively. The monthly data set consists of five macro-economic variables, which are short-term interest rates, the real effective exchange rate, net exports, the consumer price index, and the industrial production index for the period 2003 to 2010. The impulse-response function outcomes indicate that the operation of the exchange rate channel is effective, both in Turkey and in Argentina.
\end{abstract}

\section{Introduction}

Because fiscal policy has lost its luster as a tool to stabilize the aggregate economy, economists and politicians advocate that the stabilization of the real economy should be left to monetary policy. In recent years, central banks in many countries are using monetary policies to provide price stabilization (to cope with inflation) and output. In this context, monetary policy is a powerful tool used by central banks to ensure sustainable growth and low inflation in the economy. However, to be successful in conducting monetary policy (or to determine which monetary policy affects the economy), the monetary authorities must have an accurate assessment of the timing and effect of their policies on the economy.

Furthermore, they must evaluate the stance of monetary policy at a particular point in time (Mishkin 1995, 1996; Boivin, Kiley, and Mishkin 2010). In this context, monetary policy decisions are implied with changes in the money stock or in short-term interest rates. Central banks usually use short-term interest rates as a tool of monetary policy.

The effectiveness of changes in monetary policies on the real economy (output) and prices (inflation) is expressed as the result of monetary transmission mechanisms. These transmission mechanisms, which include interest rate effects, exchange rate effects, and other asset price effects, can be categorized into two basic types: neoclassical channels, in which financial markets are perfect, and non-neoclassical channels, in which financial markets are imperfect (Boivin, Kiley, and Mishkin 2010). According to this classification, neoclassical channels comprise interest rate channel, other asset price channel, and exchange rate channel. Non-neoclassical channels comprise credit channel (credit view). In addition to understanding this classification, it is important to take into account changes in expectations, which affect the relationship between monetary policy and aggregate economic activity. In this context, 'management of expectations' has become an important tool of monetary authorities throughout the world (Boivin, Kiley, and Mishkin 2010).

Therefore, expectations of economic actors' are also included in this classification as expectation channel.

Within this framework, many international studies focus on the effectiveness of the channels of the monetary transmission on the macro economic variables due to evaluate the stance of monetary policy and decide to set the accurate policy instruments for the economy. In this context the main objective of this study is to explore the effectiveness of the exchange rate channel on net exports and thereby on total output and price level using two different vector auto-regression (VAR) models. In this study, Turkey and Argentina are analyzed as the case countries because they are both emerging market countries and because they switched their fixed exchange rate regimes to floating exchange rate regimes in 2001 and 2002, respectively, after an economic crisis. Following a long period of monetary and economic turmoil, both countries have reduced their inflation through exchange rate-based stabilization programs (DTM 2002). The VAR model covers the period of 2003 to 2010, and the monthly data set consists of five macroeconomic variables, which are short-term interest rates, real effective exchange rates, net exports, the consumer price index, and the industrial production index. This study proceeds as follows: following the Introduction, Section 2 provides a theoretical background for the exchange rate channel of monetary transmission mechanisms; Section 3 summarizes recent empirical studies; Section 4 gives brief information about the exchange rate systems of Argentina and Turkey; Section 5 describes variables and discusses the empirical findings of the model and Section 6 presents the Conclusion of the study. 


\section{Monetary Transmission Mechanism Exchange Rate Channel}

With the growing internationalization of economies and the gradual increase in the implementation of floating exchange rate regimes, more attention has been paid to monetary policy transmission, which operates through exchange rates and effects on net exports. Both for developed and developing countries, one of the most important variables that affect the basic economic indicators of open economies has been the changes in exchange rates. In this

context, monetary authorities occasionally attempt the course of exchange rates with monetary policies (short-run interest rates). In this context, the monetary transmission mechanism exchange rate channel is expressed as the changes of real production and general price level, which is the result of the effect of monetary policy on exchange rates and their impact on net exports. The theoretical foundation of the exchange rate channel, which operates in open economies, is based on the Mundell-Fleming model (Bordo and Schwarts 1988; Büyükakın, Cengiz, and Türk 2009). Therefore, the exchange rate channel is more effective in open economies, which adopt floating exchange rate regimes, than it is in closed economies.

Moreover, the exchange rate channel involves interest rate effects, and it reveals the mechanism through the interest rate channel. When domestic real interest rates drop, domestic currency deposits become less attractive relative to deposits denominated in foreign currencies. This situation leads to a drop in the value of the domestic currency and an appreciation of the foreign currency (denoted by $\mathrm{E} \uparrow$ ). The lower value of the domestic currency makes domestic goods less expensive than foreign goods, which causes an increase in net exports (NX $\uparrow$ ) and, hence, in aggregate output $(\mathrm{Y} \uparrow)$.

The operation of the monetary transmission mechanism through the exchange rate channel in a monetary expansionary process is shown in the following schematic representation:

$$
\mathrm{M} \uparrow \Rightarrow \mathrm{i}_{\mathrm{r}} \downarrow \Rightarrow \mathrm{E} \uparrow \Rightarrow \mathrm{NX} \uparrow \Rightarrow \mathrm{Y} \uparrow
$$

Contrary to monetary expansion is the implementation of contractionary monetary policy. When domestic real interest rates rise, foreign capital investors will want to take advantage of this rate rise and will therefore increase capital inflow and thereby, the amount of foreign currency in the country. The rise in the amount of foreign currency leads to a drop in the value of foreign currency $(E \downarrow)$ by force of the law of supply and an appreciation of the domestic currency. Moreover, the higher values of the domestic currency make domestic goods more expensive than foreign goods and cause a decrease in net exports (NX $\downarrow$ ) and hence, a decrease in aggregate output $(\mathrm{Y} \downarrow)$. The operation of the monetary transmission mechanism through the exchange rate channel in a contractionary monetary process is shown in the following schematic representation:

$$
\mathrm{M} \downarrow \Rightarrow \mathrm{i}_{\mathrm{r}} \uparrow \Rightarrow \mathrm{E} \downarrow \Rightarrow \mathrm{NX} \downarrow \Rightarrow \mathrm{Y} \downarrow
$$

Finally, it is shown that two opposite monetary policies can affect both aggregate output and general price level (Mishkin 1995, 1996, 2001, 2007). Therefore, due to the effectiveness of changes in interest rates and exchange rates on the financial and real sectors, on the investment decisions of foreign companies and on consumer spending, it is important to consider interest rates and exchange rates during the constitution of economic policies and to ensure a stable economy and sustainable development.

\section{An Assessment of the Floating Exchange Rate Regime}

The transition from fixed or pegged exchange rates to managed floating or independently floating exchange rates has occurred gradually after the breakdown of the Bretton Woods system in 1973. While many developing countries continue to peg their exchange rates to a single currency, such as the US dollar or French franc or a basket of currencies, they, at first, shifted from single currency pegs to basket pegs in the late 1970s. Following that initiative, many developing countries over the past three decades have shifted from fixed exchange rates (that is, those that peg the domestic currency to one or more foreign currencies) and moved toward more flexible exchange rates (those that determine the external value of a currency more or less by the market supply and demand for it) (Caramazza and Aziz 1998). In floating exchange rate regimes or flexible exchange rate regimes, the currency itself is accepted as a nominal anchor, and central banks do not intervene in determining change rates (Arat 2003). Economists, analysts, and policy makers agree that determining the right exchange rate is crucial for economic stability and growth in developing countries. In this sense, exchange rates have been at the center of policy debates in developing countries for the last three decades. Emerging market economies, which have gradually combined with the increased integration of capital markets around the world, have been adversely affected by the crises in the international capital markets, such as the Mexican crisis of 1994-95, the Asian crisis of 1997-1998, the crises in Russia (May-August 1998), Brazil (from November 1998 to January 1999), and Turkey and Argentina in 2001. Therefore, the need for an appropriate exchange rate regime developed for the emerging economies (Yağcı 2001; Artus, Cartapanis, and Legros 2003; Ardıç and Selçuk 2006).

Although the debates about fixed or floating exchange rate regimes have been continuing, many economies have switched to floating exchange rate regimes since the last decade. Floating exchange rate regimes are an appropriate choice for the countries that are industrializing and for some emerging market countries that are fully 
integrated into global capital markets and have diversified production and trade, whose import and export sectors are relatively small compared to GDP and that have a deep and broad financial sector with strong prudential standards (Yağc1 2001). In this context, Turkey and Argentina are two emerging market countries that switched their fixed exchange rates to flexible exchange rates in 2001 and 2002, respectively.

\subsection{The Floating Exchange Rate Regime in Turkey}

Turkey has switched from a more controlled exchange rate regime to a flexible exchange rate regime over the past 20 years. However, many different exchange rate systems have been implemented throughout that time period. Turkey implemented a fixed but adjustable peg exchange rate regime in 02 February 1947 after it became a member of the International Monetary Funds (IMF) and the World Bank (Arat 2003:37). After the collapse of the fixed exchange rate regime, alternative regimes were adopted in Turkey. The "crawling peg" regime was implemented from 1980 until the 1994 crisis. Then Turkey employed a managed float regime between 1994 and 1999 (Görmez and Yilmaz 2007). In this application, the exchange rate was determined freely in the market, but the Central Bank could intensively intervene in determining the exchange rate. At the beginning of 2000, a 3 year stand-by agreement, signed with the IMF, and a two-term implementation strategy were initiated in the exchange rate regime. From the beginning of 2000 until February of 2001, the first term of the implementation strategy, the exchange rate-based stabilization program implemented in Turkey and the exchange rate system were based on a flexible anchor. The second phase of the program involved the band strategy, which was a gradual shift toward a more flexible exchange rate regime (Ertekin 2003; Kasman and Ayhan 2006; Görmez and Y1lmaz 2007). However, after the financial crisis in February 2001, the program failed, and Turkey started to implement the floating exchange rate regime almost a year earlier than was planned. Turkey is currently implementing a floating exchange rate regime, which started in 2002.

After the first day of the implementation of the floating exchange rate regime, exchange rates in Turkey overdepreciated (overshoot). The Turkish Lira depreciated 28.5\% against US dollar. This depreciation can happen in any country until the exchange rates reach the natural balance value of the market (Arat 2003). However, the Central Bank of Turkey announced the dynamics of the floating exchange rate as follows: exchanges rates are determined by supply and demand conditions in the market, without any exchange rate target from the Central Bank during the implementation of the floating exchange rate regime. The Central Bank also announced that it would intervene in the markets only in cases of excess volatility, without trying to affect the long-run equilibrium level of exchange rates (Görmez and Y1lmaz 2007; Y1lmaz 2008). To increase foreign currency reserves, the Central Bank implemented 'foreign exchange buying auctions to build up reserves' to quell the negative effects of internal and external shocks to Turkey as an emerging economy and to increase confidence in the country. Since April 01, 2002, the Central Bank has implemented foreign currency purchases at foreign exchange auctions, where terms and conditions are pre-announced, to minimize the impact of supply and demand conditions on the foreign exchange market (Görmez and Y1lmaz 2007; Uygur 2010). During the post-floating exchange rate regime, the Central Bank did not intervene in the foreign exchange market unnecessarily. It only intervened when expecting a significant volatility increase in this market, e.g., the volatility in financial markets observed in May and June 2006, in July 2007, and in the 2008 global crisis (October 2008). International conditions are the decisive factors for foreign currency liquidity. The Central Bank intervened in the markets and continued the foreign exchange buying auctions. It resumed the intermediary function in the foreign exchange deposit market and announced other precautions during the high level of uncertainty in the global economy. During the global financial crisis triggered in October 2008, the Central Bank suspended the foreign exchange buying auctions to reduce the financial market problems of Turkey and to strengthen the liquidity of Turkish banks (CBRT 2009). Following the recovery period of 2010, Turkey, along with inflation targeting, has been continuing to implement the floating exchange rate regime started in 2002, without using the exchange rate as a tool and without having any nominal or real target. Moreover, the Central Bank adopted a more flexible method for foreign exchange buying auctions in October 2010 and will continue to implement this method in 2011 to accelerate foreign reserve accumulation. Due to the normalization and recovery period of the global markets, the intermediary function of the Central Bank in the foreign exchange deposit market was abolished on 15 December 2010. However, the Central Bank will continue to monitor developments in the exchange rate market and will intervene through foreign exchange selling or buying auctions in case of unhealthy price formations (CBRT 2010).

\subsection{The Floating Exchange Rate Regime in Argentina}

Latin American countries' choice of an exchange rate regime has been substantially affected by historically specific degrees of freedom or urgency (Frankel and Rapetti 2010:3). After the breakdown of the Bretton Woods system, Latin American countries began to face a different international environment between the late 1960s and the early 1970s, which was the result of the shift in developed countries from fixed to floating exchange rates. Among Latin American countries, Argentina, Chile, and Uruguay had suffered economic and political crises and high inflation during the first half of the 1970s. Moreover, after the liberalization of the domestic financial system, the reduction of taxes on trade and the opening of a capital account for the balance of payments, Argentina, Chile, and Uruguay oriented their exchange rate policies towards stabilizing prices and adopting 
active crawling peg regimes in the second half of the 1970s (Frenkel and Rapetti 2010:4). In the early 1980s, the rise in international interest rates triggered massive balance of payments crises in Argentina, Brazil, Chile, Mexico, Peru, Uruguay, and Venezuela. Therefore, the crawling peg exchange rate regime was not effective, especially in Argentina, Chile, and Uruguay, because it produced current account imbalances and real exchange rate appreciation, which were the cause of slow labor market adjustments and the selection of currency baskets in the crawling peg regime (Obstfeld 1984; Drabek and Brada 1998). Due to that financial crisis, some Latin American countries, including Argentina, Brazil, and Mexico, experienced sharp devaluation and high inflation between 1982 and 1990. These three countries were able to use fixed or near-fixed exchange rates during the 1990s, which was a new period with high international liquidity and credit availability. While the use of fixed exchange rates as a nominal anchor to lower inflation is often successful, some problems started to emerge (Caramazza and Aziz 1998; IMF 2004; Frenkel and Rapetti 2010). In Argentina, the Convertibility Law was sanctioned in March 1991, according to which the currency was fixed at one peso to the dollar, under a currency board. However, this approach caused overvalued real exchange rates (IMF 2004; Frenkel and Rapetti 2007, 2010). The appreciation of the US dollar in 1997, which was the commencement date of the Argentina crisis, reduced the competitiveness of Argentina significantly. Mexican, Asian, and Brazilian crises also negatively affected the competitiveness of Argentina, and the currency board in Argentina prevented adaptation to this new situation. Therefore, from 1998 to 2000, Argentina underwent a series of adverse shocks and consequently, unfavorable economic developments (IMF 2004). Argentina was one of the countries that maintained a hard peg in the 1990s, and in the early 2000s, it announced the implementation of a new exchange rate system for exports, which extended the currency peg to include the Euro as of 15 June 2001. At the end of 2001, Argentina moved to a dual exchange rate system, adopting a preferential exchange rate peg for exports (Spiegel 2002). However, the government abandoned the dual exchange rate system, intended to control capital outflows and stabilize the foreign exchange market, and started to implement a floating exchange rate system in 11 February 2002 (DTM 2002). As a result, the currency board, through which Argentina had a highly dollarized economy, came to an end after the Argentina crisis, which was one of the most severe currency crises (Edwards 2002).

After the implementation of the floating exchange rate regime following the economic crisis, nominal exchange rate increased rapidly, and the Argentinean Central Bank ran out of foreign exchange reserves due to the economic and political uncertainties Then, as the result of the stabilization of the foreign exchange market by the Central Bank, in July 2002, through selling US dollars in the market, nominal and real exchange rates began to appreciate. However, the government started to intervene in the foreign exchange markets in the opposite direction in July 2003 due to Argentina's new exchange rate policy, oriented towards maintaining a stable and competitive real exchange rate to recover output, employment and external and fiscal balances. Although the Central Bank did not make any statement regarding the existence of a real exchange rate target, it stated that its intervention in the foreign exchange market was to protect the economy from international capital market volatility. Therefore, the joint intervention of the Central Bank and the Treasury in the foreign exchange market continued until the beginning of 2007. After the implementation of the floating exchange rate regime, the monetary transmission mechanism interest rate was considered weak and uncertain by the Central Bank authorities. In this case, Argentina started to follow a monetary policy based on broad, quantitative monetary targets, apart from the implementations of other Latin American countries (Frenkel and Rapetti 2010). From 2003, targets were announced at the beginning of every year through the Central Bank's monetary programs. From mid-2002 to mid-2008, the Argentina economy grew at an 8.5\% average annual rate because of the success of this exchange rate regime (Frenkel and Rapetti 2010). Currently, in spite of diminished domestic growth in 2008 and a mild recession in 2009 due to global economic turmoil, the economic downturn was less severe in Argentina than elsewhere. Therefore, Argentina's exchange rate policy is presently based on a managed floating exchange rate (DoS 2011).

\section{Recent Empirical Studies of the Exchange Rate Channel in Turkey and Argentina}

Channels of the monetary transmission mechanism have been examined in many international studies. A vast number of studies analyze the monetary transmission mechanism exchange rate channel in Turkey. However, there appear to be a limited number of studies that analyze the monetary transmission mechanism exchange rate channel in Argentina. In this context, the further contribution of this study is the analysis of the operation of the exchange rate channel in both Turkey and Argentina. Some recent studies that focus on the monetary transmission mechanism exchange rate channel for Turkey are summarized in the following discussion.

Generally, most of the studies that analyze the exchange rate channel for Turkey find that it operates in Turkey (Saraçoğlu and Köse 1999; Gündüz 2001; Öztürkler and Çermikli 2007; Çiçek 2005; Kasapoğlu 2007; Erdoğan and Yıldırım 2008; Örnek 2009; Büyükakın, Cengiz, and Türk 2009). The studies reveal that the exchange rate channel has a significant impact on prices (inflation). Başçı, Özel, and Sarıkaya (2008) reveal that the exchange rate channel is an important transmission channel for Turkey. They also find that in addition to its traditional effect on total demand through foreign trade, the exchange-rate channel has an important impact effective on fundamental variables, such as expectations, the risk premium, the company balance sheet, production costs and 
prices. However, these authors indicate that, after the implementation of the flexible exchange rate system following the economic crisis in 2001, the effectiveness of the exchange rate channel started to decline. They showed that low inflationary environment resulting from the implementation of structural reforms after the 2001 have increased the importance of interest rate and credit channels in Turkey compared with the pre-crisis period, which is consistent with the economic theory about monetary transmission channel. Similarly, Catik and Martin (2012) examined monthly data for the period 1986 to 2011 by using a Threshold VAR (TVAR) model to investigate changes to the macroeconomic transmission mechanism in Turkey following a major reform of monetary policy in 2004. They detected two regimes, with a clear transition between them in 2003-4. The prereform regime is characterized by high inflation and persistent responses to shocks. The post-reform regime is characterized by low inflation, more active monetary policy and less persistent responses to shocks. However, Magud et al (2012) analyzed the impact of exchange rate flexibility on domestic credit to the private sector and volume of capital flows for 12 countries, including Turkey, and found that larger share of capital inflows could be intermediated through the banking system in economies with less flexible exchange regimes, which is not in line with Başçı et al. (2008) and Catik and Martin(2012), whilst also finding that less flexible regimes are associated with a higher share of credit in foreign currency, suggesting that the impact of exchange rate flexibility is economically relevant.

A limited number of studies find varying results for Argentina. Hsing (2004) applies the VAR model to determine how real output in Argentina would react to a shock to real interest rate, the external debt/GDP ratio, real stock prices, real exchange rates, deficit spending, and the lagged output for the period of 1994 to 2003 . He finds that real GDP in Argentina responds negatively to a shock to real interest rate, the external debt ratio, or the real exchange rate and positively to a shock to real stock prices or the lagged real GDP during some of the quarters. Frenkel (2004) discusses the mechanisms by which the real effective exchange rate affects employment performance and finds that the magnitude of the real effective exchange rate effect is important for Argentina, Brazil, Chile, and Mexico. Vargas (2009) examines the relationship between net capital inflows, real exchange rates and economic growth in 20 emerging economies and compares it to a panel of 13 developed countries with a panel model. Twenty emerging economies divided into three regions, Argentina is included in the first group (Latin America and Africa), and Turkey is included in the third group. The results indicate that, unlike the situation in developed countries, credit constraints work through the exchange rate channel as an important driver of the business cycle in emerging economies. Padilla (2010) uses a series of VAR models that incorporate money market mutual funds (MMMFs) as a new endogenous variable to examine the transmission of monetary shocks to real activity, inflation, and money market funds in Argentina. According to the results, the exchange rate model shows that a currency devaluation positively impacts output but later causes inflation. The exchange rate channel is not the only source of monetary transmission to MMMFs. Friori and Amico (2010) examine the comparison of monetary policy and the inflationary process in Argentina and Brazil for the period 1990 to 2010 and find that the exchange rate channel to monetary policy has a critical importance for both Argentina and Brazil.

\section{Data and Empirical Model}

\subsection{Data Selection}

In this study, the relative effect of the monetary transmission mechanism exchange rate channel on macroeconomic variables is tested for Turkey and Argentina. For this purpose, the VAR model is used for the period of January 2003 to August 2010. All variables are internal to the VAR method, which is widely used in the analysis of monetary transmission mechanisms (Sims 1980; Asteriou and Hall 2007).

International empirical studies are taken into consideration during the selection of variables.The VAR models cover the period of January 2003 to August 2010. The data set consists of macroeconomic variables that include the following: short-term interest rates (quarterly term reel deposit interest rates, Muço et al., 2004) $(d r)$, real effective exchange rates (rexc), net exports (nexp), the industrial production index ( $i p)$, and the consumer price index $(c p)$. The symbols ' $t$ ' and ' $a$ ' represent the abbreviations for Turkey and Argentina, respectively. The real effective exchange rate and industrial production index of Argentina are provided by Bloomberg, the real effective exchange rate of Turkey comes from the Central Bank of the Republic of Turkey, and the rest of variables are from the IMF International Financial Statistics (IFS). The theoretical framework is taken into consideration during the ranking of the variables. In this framework, the VAR models used in the analysis of the exchange rate channels for Turkey and Argentina can be written as follows:

$$
\begin{aligned}
& \text { Model I: } t d r_{t} \operatorname{trexc}_{t} \operatorname{tnexp}_{t} \operatorname{tip}_{t} t c p_{t} \\
& \text { Model II: } a d r_{t} \operatorname{arexc}_{t} \operatorname{anexp}_{t} \text { aip }_{t} \operatorname{acp}_{t}
\end{aligned}
$$

\subsection{VAR Estimation}

Initially, all series should be processed for the VAR analysis. As a first step, logarithms of all variables were taken except for ' $t d r$ ', ' $a d r$ ', and 'tnexp' so that they could so that they could become independent of unit values 
(to bring them to the same level). As a second step, all variables were tested as to whether seasonality effects exist. No seasonality effect was found for the variables. In the third step, all variables were tested for whether they were stationary using the augmented Dickey-Fuller (ADF) test because all variables must be stationary in VAR models. The stationarity of all variables in Model I estimated for Turkey was questioned for a significance level at 0.01 , and all variables were found to be stationary in their first difference $I(I)$ except the 'tnexp' variable. The stationarity of all variables in Model II estimated for Argentina was also questioned for a significance level at 0.01 , and all variables were found to be stationary in their first difference $I(I)$.

Before estimating a VAR model, it is essential to determine the optimal lag length of the model. In this context, the Likelihood Ratio (LR), Final Prediction Error (FPE), Akaike Information Criteria (AIC), and Hannan-Quinn (HQ) tests were used to determine the optimal (appropriate) lag length. According to the test results, the optimal lag length was determined to be "one" for both Model I and Model II. The reliability of Model I and Model II, whose lag lengths were determined to be one, was also confirmed on the basis of the 0.05 significance level found in four diagnostic tests: the Breusch-Godfrey Serial Correlation LM, ARCH, White Heteroskedasticity, and Ramsey Reset Tests.

The variance decomposition method was used to overcome the obstacles in the interpretation of the parameters in the VAR model and to determine the source of the changes in the variable. In this context, according to the results of variance decomposition for twenty- five periods obtained from Model I and Model II, the main source of all variables' variance is explained by their own shocks. In Model I, the secondary important source of the variance of the 'trexc', 'tip', and ' $t c p$ ' variables is the ' $t d r$ ' variable, with an average 5.61\%, 1.29\%, and $19.40 \%$, respectively. Moreover, the 'trexc' variable explains the $4.90 \%$ of the forecast error variance in the ' $t c p$ ' variable as the tertiary important source. According to the variance decomposition results of Model II for the long-run and mid-term period, the ' $a d r$ ' and 'arexc' variables are secondary important sources of each other. On the other hand, the 'aip' and ' $a d r$ ' variables explain the 'anexp' variable. Shocks to the 'arexc' variable explain up to $9.42 \%$ of the forecast error variance in the 'aip' variable, and shocks to the 'anexp' variable explain up to $3.14 \%$ of the forecast error variance in the 'aip' variable. The sources of changes in variance of the 'acp' variable for the twenty-five periods are explained by the ' $a d r$ ' variable with $17.45 \%$, the 'arexc' variable with $12 \%$ and the 'aip' variable with $3.21 \%$.

The response of other variables to a shock taking place in one of the variables of the VAR model is analyzed with the impulse-response function (IRF). Therefore, with the IRF, other variables' responses to the shocks that may occur in the future could be estimated.

In this context, the responses of other variables to one standard deviation of 'trexc' shock in Model I is reported in Figure 1. The response of the 'trexc' variable to its own shock was downward from the beginning period to the fourth period. The effect of the shock disappeared after the fourth period. The response of shortterm interest rates to real effective exchange rates was downward from the initial period to the second period. However, after the foreign capital inflow, an upward trend is expected as the first response of short-term interest rates. In this context, the expected response emerged after the end of second period continued to the end of sixth period and then disappeared. The response of net exports to the 'trexc' shock was found to be downward. The reason for this outcome is that the increase in the import ratio exceeds the increase in the export ratio due to the decrease in exchange rates. Due to the drop of the ' $t d r$ ' and 'trexc' variables, industry production increases from the initial period to the end of the second period in Turkey, which has imported input dependency. The response of 'tcp' to the decrease of ' $t d r$ ' which originated from 'trexc', was upward due to the increase in household consumption. The upward tendency of 'tcp' continued to the seventh period.

The response of the short-term interest rate to its own shock was downward from the initial period to the end of the fourth period, as shown in Figure 2. After this period, the response of the ' $t d r$ ' variable to its own shock disappeared. In the process, the expected response of the 'trexc' variable is upward. In other words, the 'trexc' variable, which is acting in line with the monetary transmission mechanism, increases from the initial period to the fifth period. As the result of depreciation of domestic currency deposits against foreign currency, the demand of foreign countries for domestic goods increases and the demand of foreign goods decreases. Therefore, as an outcome of the loss of real value (an increase in the real exchange rate leads to an increase in the export ratio and a decrease in the import ratio), the 'tnexp' variable is affected positively. The response of the 'tnexp' variable continues into the beginning of the second period. That increase in the aggregate demand also affects aggregate output (tip), positively. Finally, the inflation rate increases as the result of responses of the variables in the model, which are in line with the theory. In other words, the 'tcp' variable increases from the initial period to the fifth period because of the recovery effect of the changes in the 'trexc' variable on the aggregate demand, as a response to the monetary shock.

The responses of other variables to one standard deviation 'arexc' shock in Model II are reported in Figure 3. The response of the 'arexc' variable to its own shock is downward from the initial period to the end of the fifth period. The 'arexc' shock creates an upward pressure on short-term interest. In other words, this shock causes an upward response by the ' $a d r$ ' variable from the initial period to the second period. A decrease in exchange rates causes an increase in the demand for imported goods and a decrease in the export quantity. For this reason, the 
net export rate decreased from the initial period to the second period. The changes in the 'adr' variable, which are created by the 'arexc' variable, cause a decrease in the 'aip' and 'acp' variables. Nevertheless, the response of the 'acp' variable continues up to the fourth period.
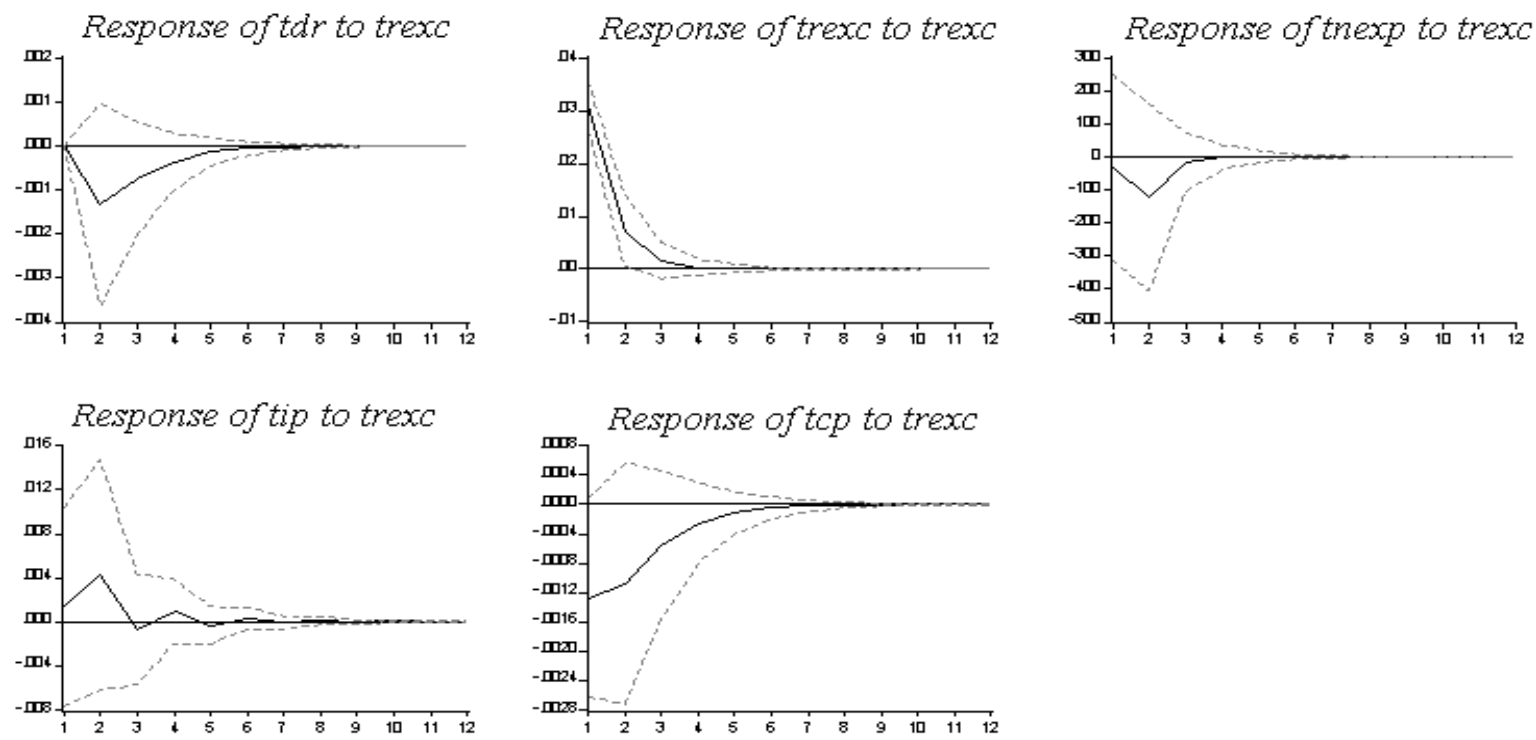

Figure 1: Response of model I variables to 'trexc'variable shock
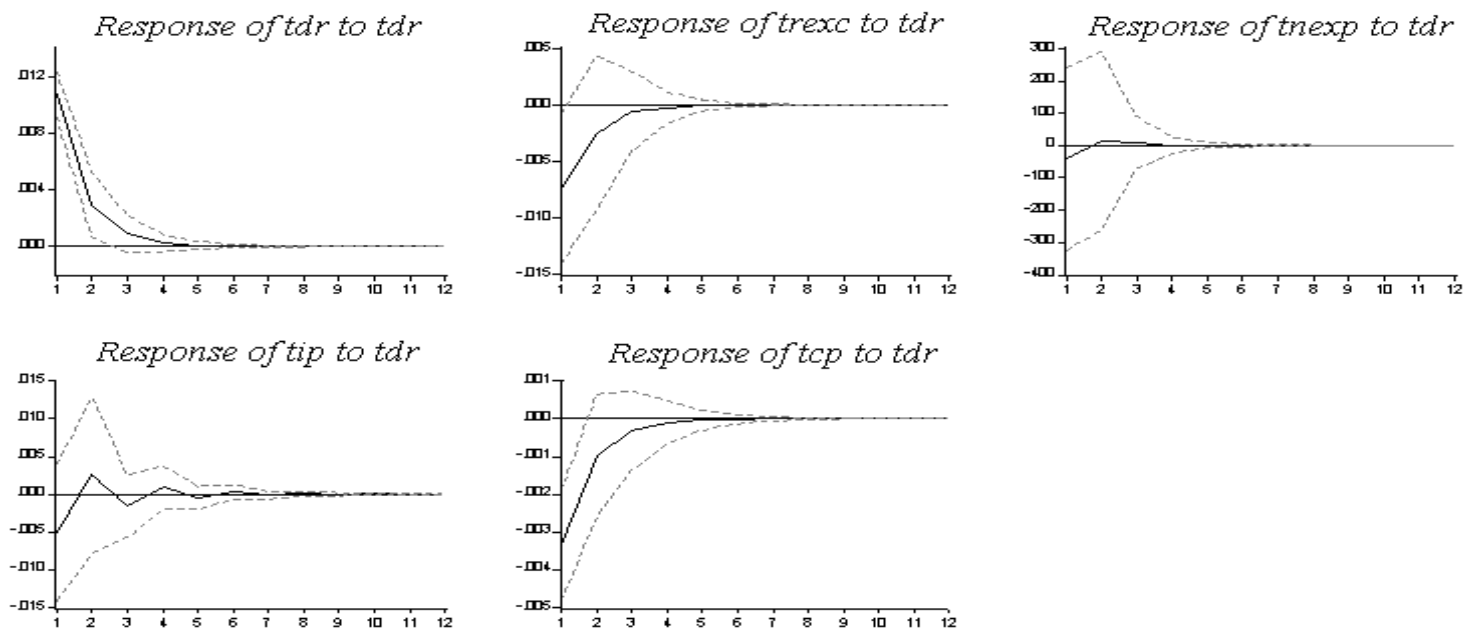

Figure 2: Response of model I variables to 'tdr'variable shock
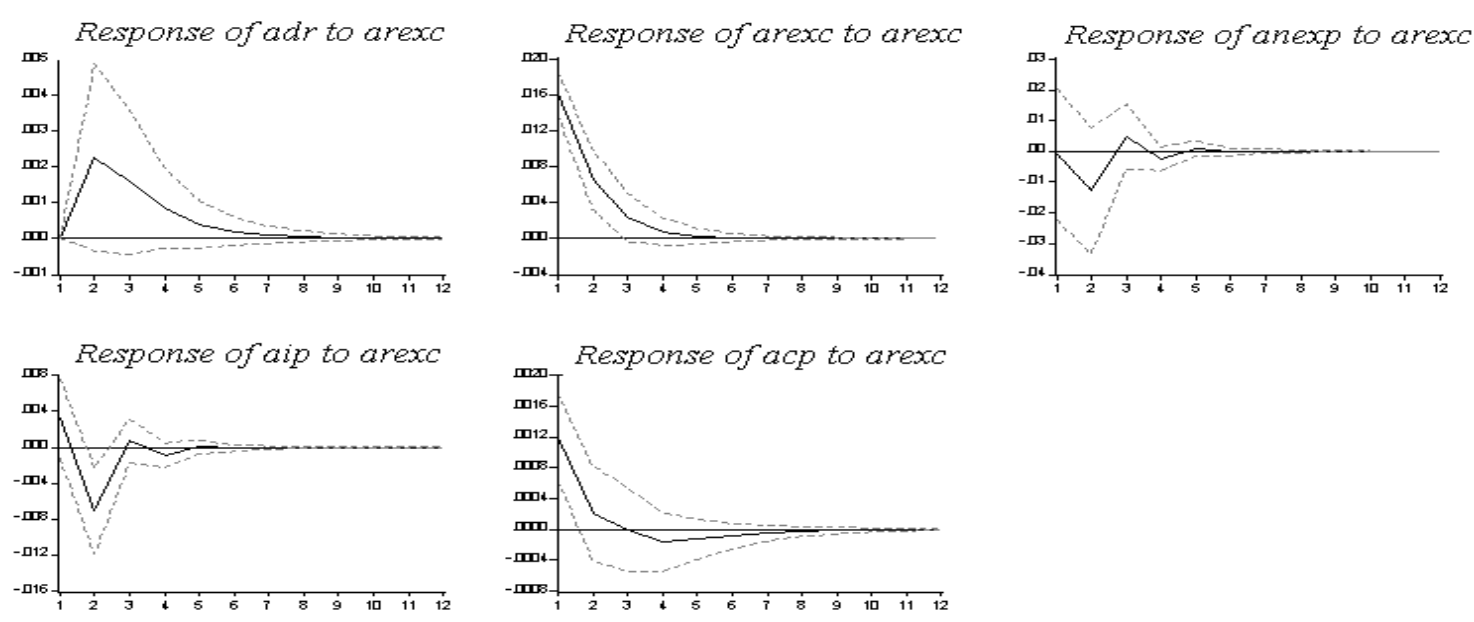

Figure 3: Response of model II variables to 'arexc'variable shock 
The responses of other variables to one standard deviation ' $a d r$ ' shock in Model II are shown in Figure 4. The response of the ' $a d r$ ' variable to its own shock from the beginning period to the fifth period downward. Although the first response of the 'arexc' variable to the 'adr' shock is downward and contradicts expectations, it is in line with expectations from the second period to the fifth period. The 'anexp' variable decreased up to the second period due to the increase in imports relative to exports, which originated from the 'arexc' variable. The effect of the shock on the 'anexp' variable comes to an end after this period.
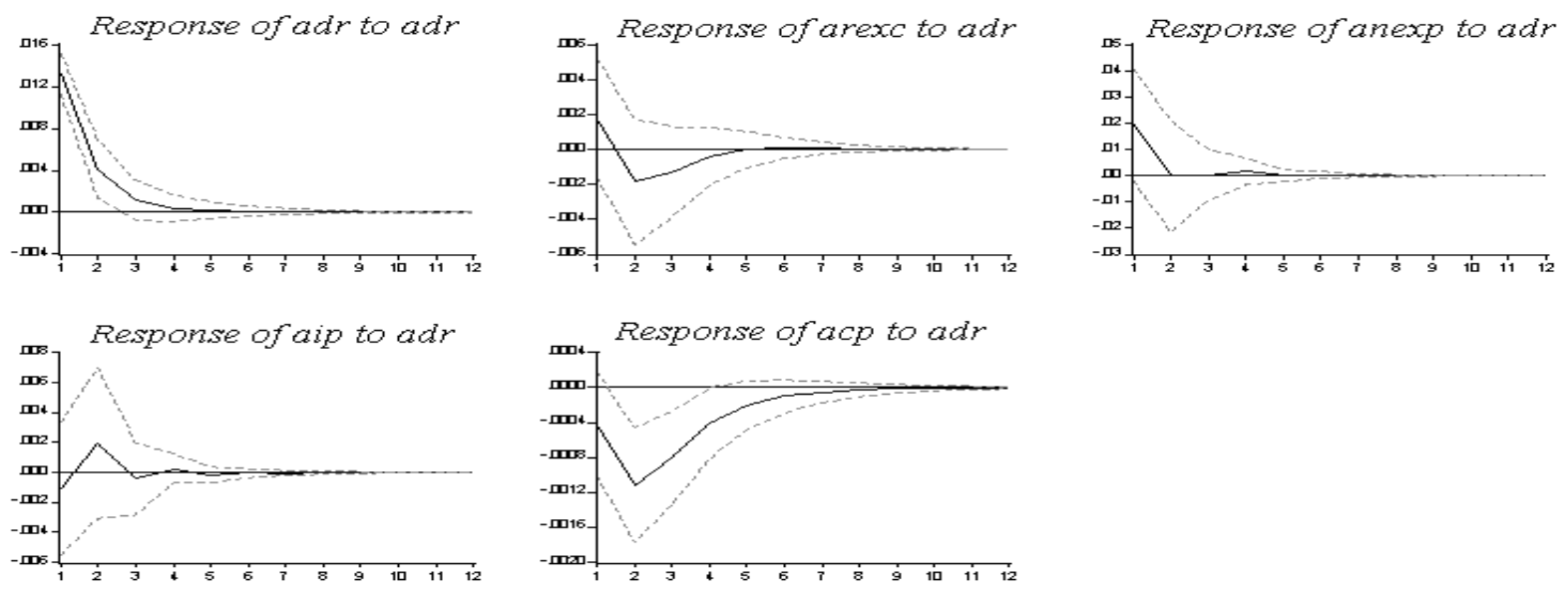

Figure 4: Response of model II variables to 'adr'variable shock

When the first responses are evaluated, it is found that the effect 'adr' shock on the 'aip' variable is positive, but that its effect on the 'acp' variable is negative. However, the expected effect of the shock on the ' $a c p$ ' variable emerged in the second period and continued until the ninth period. In this context, the lagged response of the ' $a c p$ ' variable is accepted as normal in international studies.

\section{Conclusion}

Determination of the magnitude and timing of macroeconomic variables are gaining importance in predicting the effects of shocks to the macroeconomic variables. In this context, the issue of which monetary transmission mechanism channel is more effective arises. It is important to analyze and resolve this issue on a national basis. In this framework, this study examines the effects of the exchange rate channel, which is based on the interest rate channel and is especially effective with regard to net exports, over the period of 2003 to 2010 for Turkey and Argentina, which adopted flexible exchange rate regimes in 2001 and 2002, respectively. According to the results of the impulse-response function, the exchange rate channel is effective for both Turkey and Argentina.

\section{References}

- Arat, K. (2003), “Türkiye'de Optimum Döviz Kuru Rejimi Seçimi ve Döviz Kurlarından Fiyatlara Geçiş Etkisinin İncelenmesi”, Uzmanlık Yeterlilik Tezi, TCMB Dış İlişkiler Genel Müdürlüğü, Temmuz.

- Ardiç, O. P. and F. Selçuk (2006), "The Dynamics of a Newly Floating Exchange Rate: The Turkish Case”, Applied Economics, Vol. 38, No.8, pp.931-941.

- Artus, P., A. Cartapanis and F. Legros (2003), "Towards a Macroeconomics of Exchange Rate Regimes", Revue économique, Vol.54, No. 5, pp. 905-912.

- Asteriou, D. and S.G. Hall (2007), Applied Econometrics: A Modern Approach, New York: Palgrave Macmillian

- Başçı, E., Ö. Özel and Ç. Sarıkaya (2008), "The Monetary Transmission Mechanism in Turkey: New Developments”, Bank for International Settlements (BIS) Papers No. 35, March.

- Boivin, J., M.T. Kiley and F.S. Mishkin (2010), “How Has the Monetary Transmission Mechanism Evolved over Time”, NBER Working Paper, No.15879, April.

- Bordo, M. D. and A. J. Schwartz (1988), "Transmission of Real and Monetary Disturbances under Fixed and Floating Exchange Rates”, Cato Journal, Vol. 8, No. 2, pp.451-475.

- Büyükakın, F., V. Cengiz and A. Türk (2009), "Türkiye'de Para Politikası Aktarım Mekanizması: Döviz Kuru Kanalı Üzerine Bir Değerlendirme”, Dokuz Eylül Üniversitesi İktisadi ve İdari Bilimler Fakültesi Dergisi, Vol. 24, No. 1, pp.171-198.

- Caramazza, F., J. Aziz (1998), "Fixed or Flexible? Getting the Exchange Rate Right in the 1990s", International Monetary Fund, Economic Issues no. 13, April. 
- Catik A., Martin C. (2012), "Macroeconomic Transitions and the Transmission Mechanism: Evidence from Turkey", Economic Modelling, Vol. 29, No.4, pp.440-1449.

- CBRT (Central Bank of the Republic of Turkey) (2009), Monetary and exchange rate policy for 2010, Central Bank of the Republic of Turkey, December, http://www.tcmb.gov.tr/yeni/announce/2010/Mon_Exc_Pol_2010.pdf.

- CBRT (Central Bank of the Republic of Turkey) (2010), Monetary and exchange rate policy for 2011, Central Bank of the Republic of Turkey, December, http://www.tcmb.gov.tr/yeni/announce/2010/Mon_Exc_Pol_2011.pdf.

- Çiçek, M. (2005) “Türkiye'de Parasal Aktarım Mekanizması: Var (vektör otoregregrasyonu) Yaklaşımıyla Bir Analiz", Iktisat Iş̧letme ve Finans, Vol.20, No. 233, pp. 82-105.

- DoS (U.S. Department of State) (2009), Background note: Argentina. Bureau of Western Hemisphere Affairs (July), http://www.state.gov/r/pa/ei/bgn/26516.htm.

- $\quad$ Drabek, Z. and J.C. Brada (1998), "Exchange Rate Regimes and the Stability of Trade Policy in Transition Economies", Journal of Comparative Economics, Vol.26, No. 4, pp.642-668.

- DTM (Dış Ticaret Müsteşarlığı) (2002), Arjantin ve Türkiye Ekonomik Krizleri, Ankara, http://www.foreigntrade.gov.tr/dtmadmin/upload/EAD/KonjokturIzlemeDb/arjantin.doc

- Edwards, S. (2002), “The Great Exchange Rate Debate after Argentina”, NBER Working Paper, No.9257, October.

- Erdoğan, S. and D. Ç.Yıldırım (2008), “Türkiye’de Döviz Kuru Kanalının İşleyişi: VAR Modeli ile Bir Analiz”, İstanbul Üniversitesi Siyasal Bilgiler Fakültesi Dergisi, No 39, pp. 95-108.

- Ertekin, M. (2003), Exchange Regimes and Impacts on Foreign Trade of Turkey. Republic of Turkey Ministry of Economics, http://www.ekonomi.gov.tr/upload/BF09AE98-D8D3-85664520B0D124E5614D/Murat_Ertekin-ingilizce.pdf.

- Frenkel, R. (2004), "Real Exchange Rate and Employment in Argentina, Brazil, Chile and Mexico", Iktisat İsletme ve Finans, Vol.19, No.223, pp.29-52.

- Frenkel, R. and M. Rapetti (2007), “Argentina's Monetary and Exchange Rate Policies after the Convertibility Regime Collapse”, CEPR Reports and Issue Briefs, No. 2007-12, April.

- Frenkel, R. and M. Rapetti (2010), “A Coincise History of Exchange Rate Regimes in Latin America”, CEPR Reports and Issue Briefs, No. 2010-11, Washington DC, April.

- F. Alejandro and F. Amico (2010), "Exchange Rate Policy, Distributive Conflict and Structural Heterogeneity. The Argentinean and Brazilian Cases", International Conference Sraffa's Production of Commodities by Means of Commodities 1960-2010, Roma Tre University, Faculty of Economics, Roma, December 2-4.

- Görmez, Y. and G. Y1lmaz (2007), "The Evolution of Exchange Rate Regime Choices in Turkey", Proceedings of OeNB Workshops No.13, Oesterreichische National Bank, April.

- Gündüz, L. (2001), “Türkiye'de Parasal Aktarım Mekanizması ve Banka Kredi Kanalı”, IMKB Dergisi, Vol.5, No.18, pp. 13-30

- Hsing, Y. (2002), "Responses of Argentine Output to Shocks to Monetary Policy, Fiscal Policy and Exchange Rates: A VAR Model", Applied Econometrics and International Development, Vol. 4, No.1, pp. 21-36.

- IMF (International Monetary Fund) (2004), The IMF and Argentina 1991-2001, The IMF Evaluation Report, http://www.imf.org/external/np/ieo/2004/arg/eng/pdf/report.pdf.

- Kasapoğlu, Ö. (2007), "Parasal Aktarım Mekanizmaları Türkiye için Bir Uygulama”, Uzmanlık Yeterlilik Tezi, TCMB, Piyasalar Genel Müdürlüğü, Şubat.

- Kasman, S., and D. Ayhan (2006), "Macroeconomic Volatility under Alternative Exchange Rate Regimes in Turkey”, Central Bank Review, Vol.6, No.2, pp.37-58.

- Magud N., Reinhart C. and E. Vesperoni (2012), "Capital Inflows, Exchange Rate Flexibility and Credit Booms", IMF Working Paper No.12/41, February.

- Mishkin, F.S. (1995), "Symposium on the Monetary Transmission Mechanism”, The Journal of Economic Perspectives, Vol.9, No.4, pp.3-10.

- Mishkin, F.S. (1996), “The Channels of Monetary Transmission: Lesson for Monetary Policy”, NBER Working Paper No. 5464, February.

- Mishkin, F.S. (2001), "The Transmission Mechanism and the Role of Asset Prices in Monetary Policy", NBER Working Paper No. 8617, December. 
- Mishkin, F.S. (2007), Money, Banking and Financial Markets, Pearson Education Inc: Boston.

- Muço, M., P. Sanfrey and A. Taci (2004), "Inflation, Exchange Rates and the Role of Monetary Policy in Albania”, European Bank Working Paper No. 88, August.

- Obstfeld, M. (1984), “Capital Flows, The Current Account and the Real Exchange Rate: Consequences of Liberalization and Stabilization”, NBER Working Paper No. 1526, April.

- Örnek, İ. 2009. Türkiye'de parasal aktarım mekanizması kanallarının işleyişi. Maliye Dergisi 156: 104-125.

- Öztürkler, H. and A. H. Çermikli (2007), “Türkiye'de Bir Parasal Aktarım Kanalı Olarak Banka Kredileri”, Finans Politik \& Ekonomik Yorumlar, Vol.44, No.514, pp.57-68.

- Padilla, J. L. (2010), "How Does Monetary Transmission Mechanism Impact Output, Inflation and Money Market Funds in Argentina? A VAR Approach”, Working Paper Series, University of Lausanne - School of Economics and Business Administration, February.

- Saraçoğlu, B. and N. Köse (1999), "Vektör Otoregresyon Yaklaşımı ile Enflasyonla Mücadelede Politika Seçimi: Türkiye Örneği 1980-1996”, Iktisat Ísletme ve Finans, Vol.14, No.159, pp.12-27.

- Sims, C.A. (1980), "Macroeconomics and Reality”, Econometrica, Vol. 48, No. 1, pp. 1-48.

- Spiegel, M. M. (2002), “Argentina's Currency Crisis: Lessons for Asia”, FRBSF Economic Letter, No.25, pp. 1-4.

- Uygur, E. (2010), “The Global Crisis and the Turkish Economy”, Turkish Economic Association Discussion Paper No.3, Ankara.

- Vargas, L. C. (2009), "Capital Flows and Real Exchange Rate Depreciation Effects on the Business Cycle in Emerging Markets”, Journal of Business and Policy Research, Vol. 4, No. 2, pp. 72-92.

- Yilmaz, D. (2008), “Turkey's Monetary and Exchange Rate Policy for 2009”, The Central Bank of the Republic of Turkey Research Department Discussion Paper, No. 3/2009, December. 